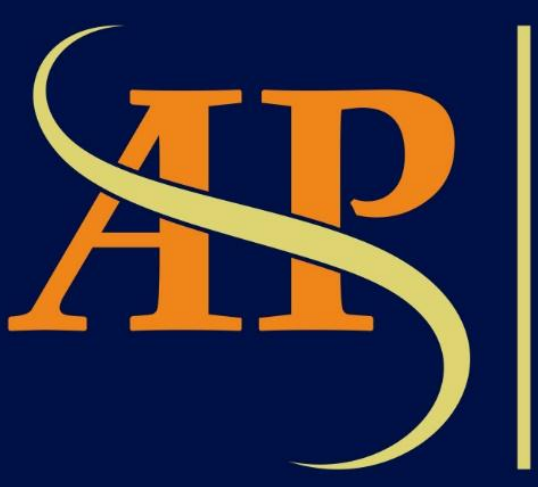

JURNAL

ASIA

PACIFIC

STUDIES

Journal of International Relations Study Program Faculty of Social and Political Sciences

Universitas Kristen Indonesia

Volume 2 | Number 1 | January - June 2018 


\title{
(TIDAK) MENYOAL DEWAN KEAMANAN NASIONAL INDONESIA
}

\author{
${ }^{1}$ Yanyan Mochamad Yani; ${ }^{2}$ Ian Montratama \\ ${ }^{1}$ Hubungan Internasional, Fakultas Ilmu Sosial dan Politik, \\ Universitas Padjadjaran, Jl. Bukit Dago Utara No.25, Bandung \\ 40135, Indonesia \\ ${ }^{2}$ Hubungan Internasional, Fakultas Komunikasi dan Diplomasi, \\ Universitas Pertamina, Jl. Teuku Nyak Arief, Simprug, Kebayoran \\ Lama, Jakarta 12220, Indonesia \\ ${ }^{1}$ yan2m@hotmail.com; ${ }^{2}$ montratama@gmail.com
}

\begin{abstract}
Almost all national security issues are multidimentional that can only be addressed by interagencies approach. That approach requires a interagencies coordinating forum to break any strategic bureucratic blockades. Such forum is known as National Security Council (NCS). In Indonesia, NCS is not created. This paper tries to analyze the function of NCS that currently being hampered due to the absence of National Security Law.
\end{abstract}

Keywords: interagencies, coordination forum, National Secuirty Council (NCS)

\begin{abstract}
Abstrak
Hampir seluruh isu Keamanan Nasional bersifat multi dimensi yang hanya bisa ditangani secara lintas kementerian/lembaga. Hal tersebut menuntut adanya forum koordinasi lintas kementerian/lembaga agar hambatan terkait birokrasi yang bersifat strategis dapat diterabas. Forum seperti itu dikenal dengan Dewan Keamanan Nasional (Wankamnas). Di Indonesia, Wankamnas belum terbentuk. Naskah ini berusaha mengkaji fungsi Wankamnas yang saat ini terkendala dengan absennya UU Keamanan Nasional.
\end{abstract}

Kata Kunci: lintas kementerian/lembaga, forum koordinasi, Dewan Keamanan Nasional (Wankamnas) 


\section{Pendahuluan}

Saat ini, dunia menghadapi ancaman multidimensi yang membutuhkan penanganan secara lintas sektoral. Contohnya seperti ancaman siber, yang tidak saja dapat menguras kekayaan seseorang namun juga dapat melumpuhkan aktivitas politik, ekonomi dan sosial suatu bangsa (manakala digunakan untuk mengacaukan sistem layanan umum, seperti perbankan, lalu lintas transportasi, jaringan data, jaringan listrik dan lain sebagainya). Contoh lainnya adalah terorisme tanpa pemimpin (leaderless terrorism), yang mana pelaku terror teradikalisasi sendiri, belajar menciptakan alat peledak sendiri dan melakukan aksi terror juga sendirian - yang sering disebut lonewolf. Penanganan aksi lonewolf sangat sulit. Dibutuhkan upaya kolektif baik dari sektor pendidikan, agama, informasi, dan keamanan.

Selain itu, ancaman tradisional berupa provokasi militer asing pun perlu disikapi dengan bijak. Selain sektor pertahanan yang mengedepankan penguatan hardpower, dibutuhkan juga upaya diplomasi pertahanan dengan tujuan untuk mempertahankan status quo dengan cara damai. Kerja sama antar industri pertahanan di kawasan dapat menjadi instrumen diplomasi yang memperkuat interdependensi dan kohesi negara-negara di kawasan.

Dengan banyaknya jenis ancaman, sudah selayaknya suatu negara harus memiliki organ yang menyediakan forum koordinasi lintas sektoral untuk mengikis segenap hambatan yang tidak dapat diatasi secara sektoral. Organ ini biasanya disebut dengan Dewan Keamanan.

Nasional (Wankamnas). Hampir seluruh negara di dunia memiliki Wankamnas. Indonesia termasuk satu dari sedikit negara lain yang belum memilikinya. Keberadaan Wankamnas merupakan tuntutan bangsa atas peran suatu pemerintahan dalam menjamin keamanan rakyatnya. Keamanan dimaksud adalah 'keamanan manusia' yang pertama kali didefinisikan dalam Laporan Pembangunan Manusia dari United Nations Development Programme (UNDP) pada tahun 1994. Dokumen ini memberikan definisi keamanan manusia yang luas yang masuk dalam tujuh kategori ancaman, yaitu: keamanan ekonomi, keamanan pangan, keamanan kesehatan, keamanan lingkungan, keamanan pribadi, keamanan masyarakat dan keamanan politik, dan terdiri dari dua elemen kebebasan, yaitu: 'kebebasan dari rasa takut dan kebebasan dari keinginan' (UNDP 1994: 24-25).

Perlindungan atas keamanan manusia umumnya diberikan pemerintah, yang merupakan lembaga sosial yang dilengkapi dengan segenap otoritas dan sumber daya yang besar. Peran pemerintah sebagai penyedia keamanan tidak bisa diganti, dan pemerintah yang dibagi dalam departemen membutuhkan forum koordinasi untuk membahas masalah keamanan yang bersifat multidimensi.

Sebenarnya telah 16 tahun berlalu sejak DPR RI mensahkan UU No. 3 tahun 2002 tentang Pertahanan Negara yang di dalamnya diamanatkan terbentuknya Dewan Pertahanan Nasional (Wanhannas). Wanhannas ini memiliki peran yang sama dengan Wankamnas. UU No. 3 tahun 2002 itu menggantikan UU No. 20 tahun 1982, sebagaimana telah diubah dengan UU No. 1 tahun 1988. Dalam UU No. 20 tahun 1982 telah diatur adanya Dewan Pertahanan Keamanan Nasional (Wanhankamnas). Namun dalam UU No. 3 tahun 2002, dipahami bahwa ada pemisahan fungsi pertahanan dan keamanan, kepada TNI dan POLRI. Sehingga nama Dewan Pertahanan Keamanan Nasional dalam UU No. 3 tahun 2002 berubah menjadi Dewan Pertahanan Nasional saja. 
Hingga kini, Dewan Pertahanan Nasional urung dibentuk. Yang ada adalah Dewan Ketahanan Nasional (Wantannas) yang dibentuk menurut intepretasi Pasal 35 ayat (3) dan (4) UU No. 20 tahun 1982/UU No 1 tahun 1988. Namun sesungguhnuya dalam UU No 20 tahun 1982, nama dewan yang dimaksud adalah Dewan Pertahanan Keamanan Nasional dan bukan Wantannas. Sehingga ada penyimpangan antara pembentukan Wantannas dengan UU yang dijadikan dasar pembentukannya.

Penyimpangan ini bersumber dari Keppres. No. 101 tahun 1999 tentang Dewan Ketahanan Nasional dan Sekretariat Jenderal Dewan Ketahanan Nasional. Pada masa awal reformasi itu, citra ABRI (nama TNI masa itu) amat buruk karena peran politiknya yang dominan, baik di pemerintah dan parlemen di tingkat pusat dan daerah, serta di sejumlah BUMN dan BUMD. Tindakan TNI yang kerap represif terhadap aksi massa dan kelompok pro-insurjen juga meninggalkan luka yang mendalam pada masyarakat yang menghendaki adanya reformasi total di tubuh TNI - untuk meninggalkan panggung politik dan bisnis.

Aspirasi masyarakat itu dapat dipahami Presiden B.J. Habibie (kala itu) dan untuk menghindari polemik pada masyarakat akan pembentukan Dewan Pertahanan dan Keamaman Nasional (Wanhankamnas), Presiden Habibie menetapkan Keppres. No. 101/1999. Latar belakang itu dijabarkan dalam konsideran Keppres tsb. sebagai berikut:

a. bahwa peran Dewan Pertahanan Keamanan Nasional perlu disesuaikan dengan perkembangan obyektif perumusan kebijaksanaan dan strategi nasional dalam rangka pembinaan ketahanan nasional;

b. bahwa dipandang perlu untuk mengubah nomenklatur, tugas dan fungsi Dewan Pertahanan Keamanan menjadi Dewan Ketahanan Nasional;

c. bahwa dengan berubahnya Dewan Pertahanan Keamanan Nasional menjadi Dewan Ketahanan Nasional, dipandang perlu untuk menyesuaikan nomenklatur, tugas dan fungsi Sekretariat Jenderal Dewan Pertahanan Keamanan Nasional menjadi Sekretariat Jenderal Dewan Ketahanan Nasional.

Mengenai perubahan nama ini, jika merujuk pada prinsip hukum ada kelemahannya. Undang-undang (yang tingkatnya lebih tinggi) tidak bisa dikalahkan oleh peraturan presiden (yang tingkatnya lebih rendah), sesuai dengan prinsip lex superiori derogat legi inferiori. Maka perubahan nomenklatur dari Wanhankamnas menjadi Wantannas diduga cacat hukum, dan demi kepastian hukum maka nomenklatur Wantannas seharusnya dikembalikan menjadi Wanhankamnas.

Namun keberadaan Wantannas berlindung dibalik Pasal 26 Aturan Peralihan UU No. 3 tahun 2002 yang berbunyi: "Pada saat berlakunya Undang-undang ini, semua peraturan pelaksanaan tentang pertahanan negara yang sudah ada dinyatakan tetap berlaku selama peraturan pelaksanaan yang baru berdasarkan Undang-undang ini belum dikeluarkan dan sepanjang peraturan itu tidak bertentangan dengan Undang-undang ini." Hal itu didukung pula oleh pasal 27 yang berbunyi: "Organisasi atau badan yang merupakan unsur penyelenggaraan pertahanan negara yang sudah ada tetap berlaku sampai dengan diubah atau diganti dengan organisasi atau badan baru berdasarkan ketentuan dalam Undangundang ini." Kemhan RI seharusnya mengajukan uji materi UU No. tahun 2002 juncto Keppres. No. 101 tahun 1999 dihadapkan pada No. 20 tahun 1982/UU No 1 tahun 1988 kepada Mahkamah Konstitusi untuk menetapkan nomenklatur yang benar antara Wanhankamnas dengan Wantannas. 


\section{Fungsi dan Tugas Dewan Pertahanan Nasional}

Dalam Pasal 13 ayat (1) UU No 3 tahun 2002 ditentukan bahwa "Presiden berwenang dan bertanggungjawab atas pengelolaan sistem pertahanan negara" dan pada pasal 13 ayat (2) ditetapkan bahwa "Dalam pengelolaan sistem pertahanan negara, sebagaimana dimaksud dalam ayat (1), Presiden menetapkan kebijakan umum pertahanan negara yang menjadi acuan bagi perencanaan, penyelenggaraan, dan pengawasan sistem pertahanan negara." Pasal 15 ayat (1) menentukan bahwa untuk menetapkan kebijaksanaan umum itu, Presiden dibantu oleh Dewan Pertahanan Nasional. Jika Pasal 15 ayat (1) menentukan Dewan Pertahanan Nasional dibentuk untuk membantu Presiden menetapkan kebijakan umum Pertahahan Negara, maka Pasal 15 ayat (2) menambah fungsi kepenasehatan Dewan Pertahanan Nasional yang meliputi pengerahan segenap komponen pertahanan negara. Pasal 15 ayat (3) lebih jauh menentukan "Dalam rangka melaksanakan fungsinya, Dewan

Pertahanan Nasional mempunyai tugas:

a. Menelaah, menilai, dan menyusun kebijakan terpadu pertahanan negara agar departemen pemerintah, lembaga pemerintah nondepartemen, dan masyarakat beserta Tentara Nasional Indonesia dapat melaksanakan tugas dan tanggung jawab masingmasing dalam mendukung penyelenggaraan pertahanan negara.

b. Menelaah, menilai, dan menyusun kebijakan terpadu pengerahan komponen pertahanan negara dalam rangka mobilisasi dan demobilisasi.

c. Menelaah dan menilai resiko dari kebijakan yang akan ditetapkan."

Dewan Pertahanan nasional dipimpin oleh Presiden RI (Pasal 15 ayat (4)) dengan anggota tetap, Wakil Presiden, Menteri Luar Negeri, Menteri Dalam Negeri, Menteri Pertahanan, dan Panglima TNI (Pasal 15 ayat (6)) dan anggota tidak tetap, yang terdiri atas pejabat pemerintah dan nonpemerintah yang dianggap perlu sesuai dengan masalah yang dihadapi (Pasal 15 ayat (6)).

Yang menjadi janggal adalah peran Presiden yang memimpin dewan yang berfungsi memberi masukan kepada Presiden sendiri. Dewan ini mempunyai fungsi sebagai penasehat Presiden dalam menetapkan kebijakan umum pertahanan dan pengerahan segenap komponen pertahanan Negara. Sebagai perbandingan, Pasal 35 UU No No. 20 tahun 1982/UU No. 1 tahun 1988 tidak menyatakan Presiden memimpin Dewan Pertahanan dan Keamanan Nasional, tetapi Keppres No. 101 tahun 1999 menentukan juga bahwa Dewan Ketahanan Nasional dipimpin oleh Presiden. Hal ini terjadi dengan Dewan Pertahanan dan Keamanan Nasional menurut Keppres No. 51 tahun 1991 tentang Perubahan Keputusan Presiden Nomor 51 Tahun 1970 tentang Dewan Pertahanan Kemanan Nasional, yang menyebut Presiden RI sebagai Ketua Dewan. Namun polemik tentang peran Presiden dalam dewan advisory ini tidak perlu dipermasalahkan. Karena Presiden dapat mengambil pelajaran atau nasehat dalam memimpin diskusi di dewan ini (seperti gaya Socrates). Kepemimpinan kepala pemerintahan juga telah menjadi suatu hal yang awam di dewan sejenis di negara lain (yang akan ditampilkan empat di antaranya di naskah ini).

Menyangkut anggota Dewan Pertahanan Nasional ini menurut UU No. 3 tahun 2002 ini anggota tetap terbatas pada Wakil Presiden, Menteri Luar Negeri, Menteri Dalam Negeri, Menteri Pertahanan dan Panglima TNI. Susunan Organisasi Dewan Ketahanan Nasional inti saat ini sesuai Pasal 7 ayat (1) Keppres No. 101 tahun 1999 adalah:

a. Ketua Dewan: Presiden Republik Indonesia;

b. Sekretaris Dewan: Sekretaris Jenderal Wantannas merangkap anggota;

c. Anggota Dewan: (1) Wakil Presiden Republik Indonesia; (2) Menteri Negara Koordinator Bidang Politik dan Keamanan; (3) Menteri Negara Koordinator Bidang Ekonomi, Keuangan, dan Industri; (4) Menteri Negara Koordinator Bidang Pengawasan 
Pembangunan dan Pendayagunaan Aparatur Negara; (5) Menteri Negara Koordinator Bidang Kesejahteraan Rakyat dan Pengentasan Kemiskinan; (6) Menteri Negara Sekretaris Negara; (7) Menteri Dalam Negeri; (8) Menteri Luar Negeri; (9) Menteri Pertahanan Keamanan; (10) Menteri Penerangan; (11) Menteri Kehakiman; (12) Panglima ABRI; (13) Kepala Badan Koordinasi Intelijen Negara.

\section{Dewan Keamanan Nasional}

Melangkah maju menuju arti penting fungsi Wankamnas, penting kiranya disepakati dahulu definisi Keamanan Nasional. Menurut Wahid (2016), definisi Keamanan Nasional belum memiliki definisi yang baku. Namun banyak pakar yang mencoba memberikan definisi Keamanan Nasional ini. Institute Defence and Security Peace Studies (IDSPS) dalam buletin bulanannya menyebutkan pengertian Keamanan Nasional adalah kemampuan negara dalam melindungi integritas wilayahnya dari gangguan yang berasal dari dalam dan luar negeri (IDSPS 2010). Pendapat senada juga diutarakan oleh Bantarto (2005) bahwa Keamanan Nasional adalah kebijakan pemerintah untuk menjamin kelangsungan hidup (survival) dan keamanan negara bangsanya (nation-state), tetapi tidak dibatasi pada pelaksanaan kekuatan diplomatik, ekonomi dan militer, baik dalam situasi damai maupun perang.

Dari dua pendapat di atas dapat disimpulkan dalam Keamanan Nasional ada dua hal yang esensial dalam mengartikan Keamanan Nasional, yaitu: pertama, adanya usaha atau aktifitas dalam rangka memberikan perlindungan kepada rakyat Indonesia; dan yang kedua, adalah adanya rasa aman bagi masyarakat yang dilindungi. Rasa aman yang dimaksud tentunya adalah rasa aman dalam semua sendi kehidupan bernegara baik sebagai pribadi maupun sebagai anggota masyarakat. Keamanan Nasional yang dimaksud tentunya bagi seluruh rakyat Indonesia. Oleh karena itu Keamanan Nasional seringkali digunakan sebagai barometer untuk menentukan tingkat stabilitas suatu negara. Dalam pengertian yang lainnya disebutkan Keamanan Nasional merupakan kebutuhan mutlak suatu negara, baik dari ancaman yang datang dari luar maupun dari dalam negeri sendiri. Upaya untuk memperoleh dan mempertahankan Keamanan Nasional tersebut merupakan tugas utama militer, terutama yang berkaitan dengan ancaman dari luar (Anwar 2004). Sedangkan jika dilihat dari sifat ancaman yang datang, Vermonte (2003) membagi masalah ancaman Keamanan Nasional menjadi dua, yaitu: yang bersifat transnasional yaitu ancaman yang berasal dari negara-negara sekitar maupun negara lainnya dan ancaman keamanan tradisional yaitu ancaman yang bersumber dari dalam negeri dan bersifat lokal.

Dua pendapat terakhir tentang Keamanan Nasional jelas menegaskan kembali bahwa betapa ancaman Keamanan Nasional (bukan hanya dari dalam namun juga dari luar) harus menjadi perhatian aktor-aktor keamanan. Dalam prakteknya upaya yang dilakukan oleh negara untuk memberikan rasa aman bagi seluruh komponen bangsa menimbulkan banyak pekerjaan yang harus dilakukan. Hal-hal strategis yang perlu dilakukan oleh negara itu antara lain: (1) memaksimalkan upaya diplomasi untuk penggalangan sekutu dan mengisolasi ancaman, (2) penataan angkatan bersenjata yang efektif, (3) konstruksi konsep pemanfaatan sipil dan kondisi-kondisi darurat (Sishankamrata), (4) memastikan daya dukung infrastruktur yang efektif, (5) penggunaan intelijen untuk melakukan deteksi dini terhadap ancaman, dan (6) pelaksanaan kontra intelijen untuk melindungi negara (IDSPS 2010).

Masalah diplomasi terhadap negara lain terutama negara tetangga yang berbatasan langsung dengan wilayah Indonesia masih belum optimal dilakukan pemerintah. Seringkali kita kalah gertak dalam politik diplomasi ini. Kasus-kasus seperti sengketa P. Sipadan dan P. Ligitan, Blok Laut Ambalat dan masalah penangkapan nelayan kita oleh tentara Malaysia dan 
China. Itu semua menjadi catatan masalah dalam diplomasi terhadap Ancaman Keamanan Nasional (AKN). Dalam penataan angkatan bersenjata, masalah yang muncul selalu pada kurangnya anggaran dan kualitas persenjataan militer kita yang jauh ketinggalan (dengan negara lain). Dalam hal kecilnya anggaran pertahanan jika dibandingkan dengan kebutuhan sangat miris dirasakan. Dalam periode 10 tahun terakhir permasalahan anggaran pertahanan telah mengemuka menjadi isu nasional yang menjadi topik kajian di berbagai kalangan stake holder Keamanan Nasional.

Anggaran pertahanan mendapat sorotan di mata publik karena dianggarkan dalam APBN dalam jumlah yang lebih kecil dari kebutuhan kekuatan minimum pertahanan (minimum essential force), dengan rata-rata anggaran masih di bawah $1 \%$ dari PDB (Produk Domestik Bruto) atau di bawah $5 \%$ dari APBN (Buku Purih Kemhan 2007). Kondisi seperti ini berdampak kepada kekuatan gelar TNI dalam operasi militer perang (OMP) maupun operasi militer selain perang (OMSP). Secara umum kemampuan sektor pertahanan dalam menghadapi Ancaman, Tantangan, Hambatan dan Gangguan (ATHG) yang akan terjadi belum memadai, bahkan berada pada taraf yang kurang dari minimal. Ini menimbulkan permasalahan di lapangan. Personil keamanan seolah punya alasan untuk bekerja tidak maksimal dalam menjalankan tugas pengamanan atau patroli.

Perwujudan Keamanan Nasional menjadi syarat mutlak bagi tetap utuhnya Negara Kesatuan Republik Indonesia. Sehubungan dengan itu, negara wajib menangkal berbagai ancaman baik yang bersifat simetrik maupun asimetrik yang dapat membahayakan kedaulatan, integritas teritorial, maupun kelangsungan hidup NKRI. Berkaitan dengan alat negara dalam perwujudan pertahanan dan keamanan nasional, Undang-Undang Dasar Negara Republik Indonesia (UUD NRI) 1945 Pasal 30 telah mengamanatkan bahwa TNI sebagai alat negara bertugas mempertahankan, melindungi, serta memelihara keutuhan dan kedaulatan negara. Adapun Polri merupakan alat negara yang menjaga keamanan dan ketertiban masyarakat bertugas melindungi, mengayomi, melayani masyarakat, dan menegakkan hukum. Mencermati hal tersebut, jelas ada pemisahan tugas dan fungsi di antara keduanya, namun demikian sesungguhnya terdapat keterkaitan dan saling ketergantungan yang erat.

Berkaitan dengan penanganan keamanan, selain TNI dan Polri juga melibatkan peran besar dari pemerintah daerah dalam hal ini Gubernur dan Bupati-Walikota. Dengan tersebarnya kapasitas penanganan Keamanan Nasional di sejumlah instansi pemerintah, proses kolaborasi di tataran operasional dapat berjalan lambat. Birokrasi yang rumit dan kaku (dan cenderung bersifat egosentris) menjadi penghambatnya. Padahal penanganan isu Keamanan Nasional menuntut terpeliharanya momentum dengan baik. Keterlambatan penanganan dapat membuat perkembangan Ancaman Keamanan Nasional (AKN) sulit untuk dikendalikan. Akibatnya, aparat pemerintah dapat 'kecolongan' dalam menanggulangi AKN. Untuk mempercepat proses birokrasi di tataran operasional, Pemerintah Indonesia perlu untuk membuat struktur pengambilan keputusan di tataran strategis (baca: kabinet). Forum koordinasi di tingkat kabinet akan memberi akses bagi instansi yang berkepentingan untuk menyampaikan kendala birokrasi yang dihadapi di lapangan untuk dicarikan solusinya oleh presiden dan para pejabat tinggi lainnya. Forum koordinasi seperti itu merupakan fenomena yang terjadi di banyak negara.

\section{Profil Wankamnas di Empat Negara}

Wacana pembentukan Wankamnas kembali muncul untuk dapat menggantikan Dewan Pertahanan Nasional. Wacana ini telah menimbulkan pro dan kontra di berbagai kalangan masyarakat dengan argumentasi bahwa Wankamnas dapat membuka luka lama masa orde 
baru dan berbenturan dengan kewenangan Polri serta dianggap sebagai langkah TNI yang ingin kembali ke panggung politik domestik. Pihak Polri mungkin lebih mengharapkan pemerintah membentuk aturan tentang tugas perbantuan TNI kepada POLRI dan sebaliknya, bukannya mengajukan RUU Kamnas dalam RPJMN 2015-2019 atau Prolegnas. Namun wacana ini tidak perlu muncul jika kita dapat secara arif menengok ke sekitar kita, terutama ke sejumlah negara maju. Bagaimana mereka menangani isu atau AKN di negaranya masingmasing. Namun yang perlu diingat bahwa dalam Peraturan Presiden RI Nomor 2 Tahun 2015 tentang RPJMN Tahun 2015-2019, pembahasan Keamanan Nasional dimunculkan kembali tentang Prioritas Penguatan Kerangka Kelembagaan 2015-2019 pada angka 1 huruf b yang menyebutkan bahwa: "Menghadirkan kembali negara untuk melindungi segenap bangsa dan memberikan rasa aman kepada seluruh warga negara, dengan pembentukan Dewan Keamanan Nasional guna membangun sistem keamanan yang integratif dan komprehensif." Berdasarkan hal tersebut, maka RUU Kamnas oleh Bappenas dimasukkan kembali dalam Prolegnas 2015-2019 untuk dibahas.

Agar pemperoleh pemahaman yang lebih baik tentang fungsi Wankamnas, naskah ini akan mengulas peran Wankamnas di empat negara lain, yaitu: Malaysia, Singapura, Australia dan Amerika Serikat. Keempat negara dinilai memiliki struktur koordinasi yang lebih maju dengan adanya Wankamnnas. Kriteria dalam pembandingnya dibatasi pada struktur organisasi koordinasi lintas lembaga pemerintah saja. Hal ini dimaksudkan agar artikel ini dapat lebih fokus mengkaji struktur organisasi koordinasi tanpa terdistraksi oleh permasalahan lain, seperti tentang penanganan $\mathrm{AKN}$ di empat negara tersebut. Hasil kajian kemudian digunakan untuk mensintesa struktur koordinasi di level strategis yang dianggap efektif untuk Indonesia, walau tanpa harus ada UU Keamanan Nasional sebagai landasan hukumnya.

\subsection{Malaysia: National Security Council (NSC)}

Pembentukan Dewan Keamanan Nasional umumnya didorong oleh adanya isu Keamanan Nasional. Demikian pula dengan Malaysia. Pada tahun 1960-an, struktur sosial Malaysia terbangun dari sejumlah ras, agama, dan ideologi yang berbeda, yang rawan konflik sosial. Masih adanya sekat sosial antara ras pribumi (baca: Melayu) dan ras pendatang (seperti India dan Cina). Masih ada pula pendukung komunisme yang tidak dapat hidup rukun dengan mayoritas penduduk Malaysia yang nasionalis. Konflik-konflik bersifat lokal bermunculan. Pemerintah Malaysia menyadari perlu adanya tindakan korektif yang cepat dengan pendekatan multi-agency untuk memelihara stabilitas Keamanan Nasional.

Pada tanggal 13 Mei 1969, Pemerintah Malaysia membentuk National Operations Council atau Majlis Gerakan Negara (MAGERAN). MAGERAN mengemban misi meningkatkan keselamatan publik, pertahanan nasional dan memelihara perdamaian untuk masyarakat umum. MAGERAN ini merupakan pelembagaan forum koordinasi di level kabinet dalam menangani isu Keamanan Nasional. Berkat koordinasi antar instansi yang efektif, stabilitas keamanan Malaysia di tahun 1970 dapat kembali kondusif. MAGERAN kemudian dibubarkan pada awal tahun 1971.

Namun belajar dari keberhasilan forum MAGERAN yang bersifat ad hoc, Pemerintah Malaysia pada tanggal 23 Februari 1971 melembagakan secara permanen forum koordinasi strategis dengan membentuk National Security Council (NSC). Misi awal NSC adalah menangani ancaman komunisme dan konflik antar ras yang masih eksis. Dewan ini berfungsi untuk mengkoordinasikan kebijakan terkait Keamanan Nasional termasuk pergerakan keamanan dan ketentraman publik. NSC dilengkapi dengan kantor sekretariat untuk menangani kegiatan administrasi dan kesekretariatan dewan. Pada tanggal 3 Desember 2015, 
NSC direorganisasi dan ditugaskan untuk: (1) berkoordinasi dengan sejumlah instansi di tingkat federal maupun negara bagian untuk masalah keselamatan nasional dan publik serta penanggulangan krisis dan bencana alam; (2) berkoordinasi dan mengeksekusi kebijakan keamanan yang diarahkan pada sejumlah instansi pemerintah untuk menjamin keselarasan atas tujuan yang telah ditetapkan; dan (3) dalam hal khusus, mengarahkan pelaksanaan operasi (Hakam 2015). NSC dilengkapi badan pelaksana seperti Federal Special Officers Team Sabah/Labuan (PPKPS/L) dan Search and Rescue Team Malaysia (SMART); (4) berkoordinasi dalam langkah-langkah terkait situasi krisis, keamanan publik, bahaya nasional dan bencana alam; dan (5) mengawasi perkembangan internal, regional dan internasional serta situasi krisis yang berdampak pada Keamanan Nasional (CLJ Law 2015).

Penegakan hukum di Malaysia semakin ketat dengan disahkannya Internal Security Act (ISA) pada tanggal 3 Desember 2015. Parlemen Malaysia telah menyetujui UU Dewan Keamanan Nasional 2015. UU yang disetujui dengan relatif cepat itu (cuma dua hari dibahas di parlemen) memberi kekuasaan berlebih kepada NSC (khususnya kepada PM) dalam menangani masalah Keamanan Nasional. Berikut ini sejumlah materi penting (Thiru 2015):

- Pada Pasal 6 dijelaskan bahwa NSC terdiri dari PM, Deputi PM, Menhan, Mendagri, Menkominfo, Mensekab, Panglima Tentara, dan Inspektur Jenderal Polisi. Seluruh pejabat tersebut dipilih oleh PM dan berada langsung di bawah PM.

- Pada Pasal 18 ayat 1 dijelaskan bahwa PM memiliki kewenangan penuh dalam menetapkan bidang keamanan.

- Pada Pasal 18 ayat 3 dan 4 dijelaskan bahwa penetapan bidang atau area keamanan berlangsung selama enam bulan namun dapat diperpanjang oleh PM tanpa batasan.

- Pada Pasal 22 hingga 30 dijelaskan bahwa aparat keamanan dapat menahan tanpa surat penahanan, melakukan penggeledahan, mengambil alih tanah, bangunan dan properti bergerak (pen: dengan dalih Keamanan Nasional).

- Pada Pasal 37 dijelaskan bahwa seluruh kegiatan NSC dilakukan dengan penuh kerahasiaan.

- Pada Pasal 38 dijelaskan bahwa tidak ada sanksi atau tuntutan atas NSC.

UU di atas menjadi suatu hal yang tidak lazim di era demokrasi liberal seperti saat ini. Kekuasaan yang dimandatkan kepada NSC menjadi sedemikian eksesif. Dahulu dengan Internal Security Act 1960, masih dituntut adanya restu Yang di-Pertuan Agong Malaysia dalam menetapkan keadaan darurat. Di UU NSC 2015, PM hanya cukup meminta nasihat delapan anggota NSC, namun PM dapat tidak menghiraukan nasihat para anggota NSC tersebut. Dengan kekuasaan PM yang lebih besar diharapkan Ancaman Keamanan Nasional (AKN) lebih mudah diberantas. Namun di sisi lain, kekuasaan berlebih tersebut membuat pemerintahan dijalankan dengan minimnya transparansi, akuntabilitas dan penghargaan pada hak individu. UU NSC memberi potensi penyalahgunaan kekuasaan oleh PM. Di satu sisi, UU NSC dapat efektif memberantas isu AKN, namun di sisi lain, demokrasi terdegradasi.

\subsection{Singapura: National Security Coordination Secretariat (NSCS)}

Di Singapura, AKN yang paling utama adalah terorisme. Sebagai upaya untuk menangani terorisme serta AKN secara umum, Singapura mengeluarkan kebijakan pertahanan yang dinamakan "Total Defense" (Carpenter 2005). Kebijakan ini terdiri dari tiga elemen dasar, yaitu; pencegahan, perlindungan dan respons dalam menghadapi AKN. Lebih jauh, kebijakan ini memiliki lima pilar dimensi yang terkait satu dengan yang lainnya dalam mengatasi AKN, yaitu: dimensi militer, psikologi, sosial, sipil dan ekonomi, dan melibatkan 
pula partisipasi masyarakat Singapura secara total (Kemhan Singapura 2004). Dahulu penanganan AKN dilakukan secara sektoral. Untuk ancaman tradisional ditangani oleh Angkatan Perang Singapura dan Kementerian Pertahanan. Sedangkan untuk keamanan internal merupakan tanggung jawab lembaga Home Team yang terdiri dari kepolisian dan Kementerian Dalam Negeri. Namun AKN transnasional membutuhkan penanganan lintas lembaga pemerintah.

Penanganan AKN di Singapura dilakukan melalui koordinasi terpusat, yaitu di bawah kantor PM. Pusat koordinasi berkewajiban menetapkan arah kebijakan Keamanan Nasional untuk dilaksanakan sejumlah lembaga pelaksana. Pusat koordinasi mengadakan forum komunikasi strategis untuk mendiskusikan isu strategis dan menyelaraskan pandangan atas masalah keamanan ke seluruh pembuat dan pelaksana kebijakan. Pusat koordinasi Keamanan Nasional Singapura dilembagakan dengan nama National Security Coordination Secretariat (NSCS) yang dibentuk pada tahun 1999. Lembaga ini bekerja di bawah panduan Security Policy Review Committee (SPRC) yang beranggotakan Menko Hankam, Menhan, Mendagri, dan Menlu.

Kedudukan NSCS berada di bawah kantor PM, dengan tugas merencanakan struktur dan proses Keamanan Nasional dan mengkoordinasikan kebijakan dan isu intelijen. Pimpinan NSCS dijabat oleh Permanent Secretary for National Security and Intelligence Coordination. Permanent Secretary melapor langsung ke PM melalui Menko Hankam. Permanent Secretary juga memimpin Intelligence Coordinating Committee yang memimpin koordinasi aktivitas intelijen Singapura (National Security Coordination Secretariat 2016).

Pada awal tahun 2000-an, NSCS dilengkapi dengan dua unit pelaksana tugas, yaitu: National Security Coordination Centre (NSCC) dan Joint Counter Terrorism Centre (JCTC) untuk mendukung fungsi kebijakan dan intelijen. NSCC terdiri dari sejumlah bagian yang mengurusi kebijakan, perencanaan, penilaian resiko, dan horizon-scanning - melalui pengoperasian Horizon Scanning Centre (National Security Coordination Secretariat 2016).

Namun dalam keadaan darurat, Singapura memiliki lembaga lain yang dibangun sejak tahun 1978 yang dinamakan Executive Group (EG). EG merupakan sistem yang sudah teruji, sejak penanganan runtuhnya Hotel New World di tahun 1986 hingga pembajakan pesawat Singapore Airline nomor SQ 117 di tahun 1991. Pada tahun 2003, EG diaktivasi untuk mengkoordinasikan respons terhadap krisis virus SARS (flu burung). Sebagai bentuk pengawasan atas koordinasi dan kolaborasi antar lembaga di Singapura, dibentuk empat komite, yaitu (1) Security Policy Review Committee (SPRC); (2) National Security Coordinating Committee (NSCComm); (3) Intelligence Coordinating Committee (ICC); dan (4) Inter-Ministry Committees atau IMCs (National Security Coordination Centre 2016).

Security Policy Review Committee (SPRC) yang dipimpin oleh Menko Hankam ini bertugas memformulasikan rencana dan kebijakan Keamanan Nasional. National Security Coordinating Committee (NSCComm) yang dipimpin Permanent Secretary for National Security and Intelligence Coordination merupakan Executive Committee yang berada di bawah SPRC yang mendukung dan mengeksekusi kebijakan SPRC. Intelligence Coordinating Committee (ICC) melakukan kajian atas AKN serta memberi arahan pada analisa strategis dan aksi lanjutan. ICC dipimpin oleh Permanent Secretary for National Security and Intelligence Coordination, dan berada di bawah SPRC. NCCS yang juga dipimpin oleh Permanent Secretary for National Security and Intelligence Coordination memiliki tiga badan penunjang, yaitu: National Security Coordination Centre, National Security Research Centre dan Resilience Policy and Research Centre (Kemhan Singapura 2016).

National Security Coordination Centre (NSCC) memperkuat koordinasi dan kolaborasi lintas lembaga dengan memimpin dan memfasilitasi program kerja yang mendukung Keamanan Nasional. NSCC bekerjasama dengan sejumlah kementerian untuk menangani 
ancaman di bidang keamanan maritim, keamanan penerbangan, keamanan transportasi publik, perlindungan prasarana kritikal, keamanan siber, kendali perbatasan, dan pertahanan atas CBRE (chemical, biological, radiological and explosive). Sementara National Security Research Centre (NSRC) adalah lembaga pengganti Joint Counter-Terrorism Centre (JCTC) yang berdiri sejak tahun 2004. NSRC bertugas melakukan kajian atas AKN dengan program utamanya: penilaian resiko atas kepentingan keamanan. Kajian ini dilakukan bekerjasama dengan lembaga pemerintah lainnya. Namun sejak pertengahan tahun 2011, bidang kerja JCTC meluas di luar isu terorisme. Sehingga JCTC dirubah namanya menjadi NSRC pada tanggal 1 Mei 2012. Tugas NSRC adalah melakukan kajian strategis dan antisipatif atas AKN dalam mendukung formulasi rencana dan kebijakan serta pembangunan kemampuan (National Security Coordination Secretariat 2016).

Resilience Policy and Research Centre (RPRC) adalah badan koordinasi ketahanan yang bertugas merencanakan dan mengkoordinasikan program pembuatan kebijakan dan penelitian bidang ketahanan sosial. Ketahanan sosial didefinisikan sebagai kemampuan kolektif masyarakat, lembaga pemerintah dan institusi sipil, serta komunitas dalam menghadapi tantangan dan kemunduran (fasilitas umum), beradaptasi dalam lingkungan setelah kemunduran, dan mengintegrasikan hikmah untuk menjadikan Singapura lebih kuat lagi. RPRC membangun jaringan penelitian untuk mengkoordinasikan riset, mengamankan sumberdaya untuk riset lanjutan di bidang ketahanan, dan bekerja sama dengan kembaga lain untuk melakukan kajian dan mendistribusikan penemuan.

NSCC juga bekerja sama dengan pusat kompetensi nasional, seperti dengan: (1) National Security Engineering Centre (NSEC) yang dibangun pada bulan November 2005 dengan berkolaborasi dengan Defence Science and Technology Agency (DSTA) dalam mendukung aspek teknologi dan rekayasa untuk memenuhi kebutuhan pertahanan dan Keamanan Nasional Singapura. NSEC melakukan technology road mapping di tingkat strategis; (2) Centre of Excellence for National Security (CENS) yang merupakan lembaga kajian dari S. Rajaratnam School of International Studies (RSIS) di Nanyang Technological University of Singapore (NTU). CENS didirikan pada bulan April 2006 untuk melakukan riset dan kajian kebijakan bidang Keamanan Nasional. Ada tiga bidang kajian utamanya yaitu: studi radikalisasi, ketahanan sosial, dan pertahanan negara (terutama dalam kaitan dengan manajemen resiko dan komunikasi krisis); (3) NSCS Programme on Interdependency Assessment and Studies (NIDAS) yang didirikan pada tahun 2012 dan berkolaborasi dengan DSO National Laboratories dengan tugas menjadi national focal point untuk studi interdependensi dalam dan antar domain yang mempengaruhi Keamanan Nasional Singapura (National Security Coordination Secretariat 2016).

Dengan anggaran pemerintah yang memadai, pemerintah Singapura telah membangun struktur koordinasi penanganan AKN dengan sangat komprehensif. Namun struktur yang kompleks di atas justru berpotensi menimbulkan duplikasi tugas yang dapat membuat konflik kewenangan (jurisdiksi) antar lembaga di lapangan. Hal tersebut justru akan memperlambat penanganan $\mathrm{AKN}$ yang bertentangan dengan tujuan awal pembentukan struktur di atas.

\subsection{Australia: National Security Committee (NSC) of Cabinet}

AKN utama Australia adalah terorisme. Namun ancaman tersebut lebih merupakan ancaman aksi teror atas warga Australia di luar negeri, ketimbang di dalam negeri. Lokasi geografis Australia yang terpencil dan penjagaan wilayah perbatasannya yang sangat ketat, membuat kelompok teroris sulit masuk ke Australia. Kelompok teroris kerap menjadikan 
warga Australia di Asia Tenggara sebagai sasaran utamanya. Sudah terjadi empat aksi teror dengan sasaran warga Australia antara tahun 2002 hingga 2005. Hal tersebut didorong oleh kebijakan luar negeri Australia yang dianggap memprovokasi kepentingan kelompok teroris tersebut. Kebijakan Australia yang telah berkoalisi dengan militer Amerika Serikat di front Afganistan, Irak dan Libya, tentu mengganggu kepentingan kelompok teroris tertentu. Sementara jumlah warga Australia di Indonesia (terutama di Bali) sangat banyak. Hal tersebut menjadikannya sasaran empuk bagi aksi teroris.

Forum koordinasi Keamanan Nasional di Australia dilembagakan dengan nama National Security Committee (NSC) of Cabinet yang merupakan komite dalam kabinet dan menjadi pengambil keputusan puncak untuk masalah Keamanan Nasional, intelijen, dan pertahanan. NSC dipimpin oleh PM dan beranggotakan Wakil PM, Jaksa Agung, Menlu, Menhan, Sekretaris dari departemen jasa publik, Kepala Angkatan Perang, National Security Advisor, Direktur Jenderal Keamanan, Direktur Jenderal Office of National Assessments dan Kepala Australian Secret Intelligence Service. Dalam menjalankan tugasnya, NSC dibantu oleh Secretaries Committee on National Security (SCNS) yang dahulu bernama Secretaries Committee on Intelligence and Security. SCNS menangani segala hal penting untuk dilaporkan ke NSC melalui pendekatan koordinasi kebijakan (Kejaksaan Agung Australia 2016).

Anggota SCNS meliputi Secretary of the Department of the Prime Minister and Cabinet, Associate Secretary for National Security and International Policy of the Department of the Prime Minister and Cabinet, Secretary of the Attorney-General's Department, Secretary of the Department of Foreign Affairs and Trade, Secretary of the Department of Defence, Secretary of the Department of the Treasury, Chief of the Australian Defence Force, dan Director-General of the Office of National Assessments. Anggota lainnya dapat meliputi Komisioner Kepolisian Federal Australia, Chief Executive Officer dari Australian Customs and Border Protection Service, dan Chief Executive Officer dari Australian Crime Commission, dan Kepala ASIO, ASIS, AGD, ASD, dan DIO, manakala dibutuhkan (ANAO 2011).

Sementara di dalam kantor PM juga ada badan yang bernama National Security and International Policy Group (NSIPG) yang dipimpin oleh Associate Secretary for National Security and International Policy. NSIPG bertugas memberi saran atas kebijakan luar negeri, perdagangan, traktat, pertahanan, intelijen, non-proliferasi, pemberantasan terorisme, penegakkan hukum, keamanan perbatasan, pengelolaan keadaan darurat; mengkoordinasikan kajian ilmu dan teknologi terkait keamanan; dan mengkoordinasikan peran kepemimpinan dalam pembangunan kebijakan Keamanan Nasional.

NSIPG memiliki tiga divisi yang dipimpin masing-masing oleh First Assistant Secretary, yaitu: (1) Divisi Internasional yang memberi saran dan mengkoordinasikan masalah dan prioritas kebijakan luar negeri, perdagangan, bantuan dan traktat, termasuk hubungan bilateral dan hubungan dengan organisasi regional dan internasional, negosiasi pasar bebas, dan menangani prioritas program bantuan ke luar negeri. Divisi ini terbagi dalam bagian Asia Pasifik, Amerika, Timur Tengah dan Asia Utara, serta Multilateral dan Perdagangan; (2) Divisi Keamanan Nasional yang memberi saran, koordinasi dan kepemimpinan pada kebijakan, prioritas, dan strategi yang menyangkut operasi militer, strategi pertahanan. Pemberantasan terorisme, dan proteksi prasarana kritikal. Divisi ini terbagi dalam bagian Pertahanan dan Keamanan Domestik; (3) Divisi Kebijakan Siber dan Intelijen yang memberi saran, koordinasi dan kepemimpinan tentang kebijakan, prioritas dan strategi di bidang keamanan siber, terorisme siber, dan intelijen. Divisi ini terbagi dalam bagian Intelijen dan Kebijakan Siber (Departemen Perdana Menteri dan Kabinet Australia 2016). 
Sementara untuk badan pelaksana atau eksekutor, di Australia terdapat sejumlah lembaga terkait Keamanan Nasional seperti (Buku Putih Penanganan Terorisme Australia 2010), yaitu:

- Australian Security Intelligence Organisation (ASIO) yang merupakan instansi Keamanan Nasional dengan tugas utama mencari informasi dan memproduksi intelijen yang menyadarkan pemerintah atas aktivitas dan situasi yang dapat membahayakan Keamanan Nasional Australia. ASIO memiliki sejumlah badan seperti : (1) Counter-Terrorism Control Centre yang bertugas dalam menerapkan dan mengelola prioritas pemberantasan terorisme, mengidentifikasi kebutuhan intelijen, dan menjamin proses koleksi dan distribusi informasi pemberantasan terorisme dapat selaras dan efektif; (2) National Threat Assessment Centre juga bagian dari ASIO yang bertanggungjawab dalam menganalisis ancaman teroris atas kepentingan Australia di luar negeri dan ancaman teroris dan kekejaman dari demonstrasi di Australia; (3) National Threat Assessment Centre (NTAC) bertugas menyiapkan kajian atas kemungkinan dari munculnya terorisme dan kekejaman demonstrasi, termasuk yang melawan Australia, warga negara Australia, dan kepentingan Australia di dalam dan luar negeri, atas peristiwa khusus dan kepentingan internasional di Australia; (4) Business Liaison Unit (BLU) menjadi penghubung antara sektor swasta dan komunitas intelijen Australia; (5) Counter Terrorism Control Centre (CTCC) bertugas menetapkan dan mengelola prioritas pemberantasan terorisme, mengidentifikasi kebutuhan intelijen, dan menjamin proses pengumpulan dan distribusi informasi pemberantasan terorisme dapat selaras dan efektif diterima of komunitas lembaga pemberantasan terorisme. CTCC beranggotakan pejabat senior dari ASIS, AFP, ASD, dan AGO.

- Australian Secret Intelligence Service (ASIS) adalah badan intelijen yang menggunakan agen rahasia di luar negeri dengan misi untuk melindungi dan mendukung kepentingan vital Australia melalui kegiatan intelijen rahasia luar negeri. Tujuan utama ASIS adalah mendapatkan dan mendistribusikan intelijen rahasia tentang kemampuan, intensi, dan aktivitas individu atau organisasi di luar Australia, yang dapat berdampak pada kepentingan Australia dan ketentraman penduduknya.

- Office of National Assessments (ONA) bertugas membuat kajian atas perkembangan politik internasional, isu strategis dan ekonomi sebagai lembaga independen yang bertanggungjawab langsung kepada PM dan memberi saran dan kajian pada menteri senior lain di National Security Committee of Cabinet dan Senior Officials of Government Departments. ONA beroperasi di bawah legislasinya dan bertanggungjawab untuk berkoordinasi dan mengevaluasi kegiatan intelijen luar negeri Asutralia. ONA mengumpulkan informasi dari badan inetelijen, laporan diplomatik, lembaga pemerintah dan sumber umum. ONA memiliki badan di bawahnya yang disebut dengan Open Source Centre (OSC) yang mengumpulkan, mengkaji, dan menganalisa informasi dari sumber umum untuk mendukung Keamanan Nasional Australia.

- Defence Intelligence and Security Group (DISG) adalah badan di bawah Kementrian Pertahanan yang mengkoordinasikan kebijakan intelijen, keamanan dan isu strategis lain. DISG dibagi ke dalam empat sub bagian, yang mana tiga sub badan berikut menjadi badan intelijen utama Australia, yaitu: (1) Australian Geospatial-Intelligence Organisation (AGO) adalah penyatuan Australian Imagery Organisation, Directorate of Strategic Military Geographic Information, dan Defence Topographic Agency yang memberikan intelijen geospasial, dari citra gambar atau sumber lain, yang mendukung Angkatan Perang Australia dan kepentingan Keamanan Nasional; (2) Defence Intelligence Organisation (DIO) adalah badan intelijen militer nasional dan badan pengkajian intelijen yang memberikan layanan dan saran pada tingkat Keamanan Nasional dengan mandat untuk mendukung Angkatan Perang, Kemhan, Pemerintah Australia dan pengambilan keputusan Keamanan Nasional dan untuk mendukung perencanaan dan kegiatan operasi Angkatan Perang Australia; (3) Australian Signals Directorate (ASD) bertugas untuk mengumpulkan, 
menganalisa, dan mendistribusikan sinyal intelijen asing dan menjadi otoritas nasional untuk komunikasi, informasi, siber dan keamanan komputer. ASD memiliki Cyber Security Operations Centre yang mengkoordinasikan dan membantu respons operasional atas peristiwa siber yang menyangkut kepentingan nasional dan memberi pemerintah pemahaman atas ancaman siber melalui kemampuan deteksi kebocoran, analisa, dan kajian ancaman; dan (4) Australian Cyber Security Centre (ACSC) yang juga berada di bawah ASD bertanggungjawab atas operasi dan koordinasi keamanan teknologi komunikasi. ASC mengidentifikasi dan mengkaji potensi ancaman dan memberi kemampuan dan teknik analisis untuk merespon kejahatan siber, terorisme siber, dan cyberwarfare.

Struktur penanganana AKN di Australia mirip dengan Malaysia dan Singapura dalam aspek kompleksitasnya. Hal tersebut menandakan bahwa AKN ditangani secara multi lembaga, karena perkembangan AKN sendiri bersifat multi-dimensi. AKN tidak saja berupa aksi pengeboman, namun bisa juga serangan siber, sabotase atas fasilitas umum, pembajakan, epidemi, dan lain sebagainya. Namun struktur penanganan yang sangat kompleks seperti di atas justru akan membutuhkan sistem koordinasi yang lebih superior lagi, selain menyedot anggaran yang sangat besar.

\subsection{Amerika Serikat: United States National Security Council (NSC)}

Pasca tragedi runtuhnya menara kembar WTC di Kota New York pada tanggal 11 September 2001, kebijakan Keamanan Nasional Amerika Serikat berubah drastis. Presiden George W. Bush mencanangkan perang global melawan teror dengan memerangi kelompok teroris internasional langsung di sarangnya. Kelompok al-Qaeda yang dipimpin Osama bin Laden dianggap sebagai pihak yang paling bertanggung jawab atas tragedi 9/11. Data intelijen mengarahkan Amerika Serikat menuju Afghanistan, negara yang gagal ditaklukkan Rusia. Genderang global war on teror telah dimulai. Amerika Serikat tidak punya pilihan lain, selain membuka front Afganistan untuk memerangi al-Qaeda.

Amerika Serikat pun akhirnya semakin gencar dalam memerangi terorisme internasional di berbagai negara. Terorisme menjadi agenda utama Keamanan Nasional AS. Puncak keberhasilan perang atas terorisme adalah saat penyerbuan ke sarang Osama bin Laden pada tanggal 1 Mei 2011. Presiden Barrack Obama memimpin forum koordinasi Keamanan Nasional untuk mengawasi misi penangkapan Osama bin Laden. Di Amerika Serikat, forum koordinasi Keamanan Nasional tersebut dilembagakan dengan nama National Security Council (NSC) yang berkedudukan di Gedung Putih. NSC merupakan bagian dari Executive Office of the President of the United States. NSC dibentuk di masa pemerintahan Presiden Harry S. Truman yang membantu Presiden AS atas kebijakan bidang Keamanan Nasional dan luar negeri. NSC juga merupakan alat utama Presiden AS dalam berkoordinasi tentang kebijakan Keamanan Nasional dan luar negeri dengan berbagai lembaga pemerintah lainnya.

National Security Council didirikan pada tahun 1947 melalui National Security Act (PL 235 - 61 Stat. 496; U.S.C. 402) yang diamandemen dengan National Security Act Amendments o1949 (63 Stat. 579; 50 U.S.C. 401 et seq.) dan pada tahun 1949, sebagai bagian dari Reorganization Plan, NSC ditempatkan di bawah Executive Office of the President. NSC dibentuk karena disadari bahwa diplomasi Kementerian Luar Negeri masih kurang mampu membendung Uni Soviet di masa awal Perang Dingin. Diharapkan NSC mampu menjamin koordinasi dan keselarasan AD, Korps Marinir, AL, AU, dan instrumen kebijakan Keamanan Nasional lain seperti CIA - yang juga dibentuk dari National Security Act (1947, halaman 1).

NSC dipimpin langsung oleh Presiden AS dengan anggota intinya adalah Wapres, Menlu, Menhan. Anggota lain dapat ditambahkan seperti National Security Advisor dan 
merupakan statutory military advisor di NSC, Director of National Intelligence sebagai statutory intelligence advisor, dan Director of National Drug Control Policy sebagai statutory drug control policy advisor. Sementara Chief of Staff to the President, Counsel to the President, dan Assistant to the President for Economic Policy juga secara rutin diundang pada pertemuan NSC. Jaksa Agung, Director of the Office of Management and Budget serta Direktur CIA diundang sesuai dengan kapasitasnya. Kepala kementerian dan lembaga pemerintah lainnya dapat diundang jika diperlukan (NSA 1947, halaman 2).

Pada tanggal 26 Mei 2009, Presiden Barack Obama menggabungkan staf Gedung Putih untuk mendukung Homeland Security Council (HSC) dan National Security Council (NSC) ke dalam National Security Staff atau NSS (Gedung Putih 2016). Dalam perkembangan sejarah, NSC mempengaruhi proses pengambilan keputusan di Gedung Putih secara signifikan. NSC memiliki sejumlah badan pelaksana, di antaranya High Value Detainee Interrogation Group dan juga memiliki otoritas untuk memerintahkan pembunuhan. Panel NSC rahasia dapat menetapkan sasaran pembunuhan terhadap individu yang dianggap tersangka teroris. Penetapan sasaran pembunuhan tidak akan tercatat untuk publik dan tidak ada aturan yang mengatur tatacara dan memberi mandat penetapan sasaran pembunuhan. Namun parlemen AS telah menyetujui Patriot Act yang mengijinkan Presiden AS untuk mengambil alih properti orang asing yang menjadi tersangka teroris yang berencana menyerang AS. UU ini juga memperbolehkan penyadapan atas pembicaraan telepon (Kementerian Kehakiman AS 2016, Pasal 1 Butir ke-2).

Selain NSC, peran National Security Advisor (NSA) cukup penting dalam proses pengambilan keputusan bidang Keamanan Nasional di AS. NSA bekerja di kantor eksekutif Gedung Putih. NSA mendapat kedudukan setingkat menteri yang perannya sejajar dengan Menteri Luar Negeri, Menteri Pertahanan dan Menteri Keamanan Tanah Air. Penunjukkan pejabat NSA tidak memerlukan persetujuan parlemen AS. Hal ini membebaskan pejabat NSA dari tekanan politik dari partisan. Beberapa tokoh yang pernah menjabat NSA adalah: Henry Kissinger (di masa Presiden Richard Nixon dan Gerald Ford), Jenderal Colin Powell (di masa Presiden Reagan) dan Condeleza Rice (di masa Presiden George W. Bush). Tugas utama NSA adalah mengawasi staf Dewan Keamanan Nasional dan bertanggungjawab dalam mengkoordinasikan administrasi kebijakan luar negeri, intelijen dan kegiatan militer (Burke 2009). Namun tugas dan tanggungjawab ini dapat berkembang sesuai dengan kehendak Presiden AS.

Sebagai negara demokrasi terbesar dan tertua di dunia, struktur penanganan AKN ternyata bersifat otokratif. Dengan alasan Keamanan Nasional, aparat pemerintah berhak untuk membelenggu hak dasar individu, bahkan untuk membunuh seseorang yang dianggap sebagai AKN seperti tersangka teroris. Penanganan AKN di AS selain kompleks juga didukung aturan. Kongres yang mewakili rakyat AS telah setuju untuk mengurangi hak dasar individu demi Keamanan Nasional yang lebih luas (greater good).

\section{Rekomendasi bagi Pemerintah Indonesia}

Dari ulasan forum koordinasi di empat negara, terdapat sejumlah kesamaan yang dapat dicontoh bagi struktur pengambilan keputusan strategis bidang Keamanan Nasional di Indonesia. Seluruh negara menggunakan pendekatan multi-agency dalam menangani AKN dan pusat koordinasinya berada di bawah kantor kepala pemerintahan. AKN disadari bersifat multi dimensi. Kemunculan AKN dapat didorong oleh faktor ekonomi (selain masalah politik 
dan keyakinan) seperti kesenjangan antara kaya dan miskin, besarnya angka pengangguran dan makin tingginya biaya hidup. Masalah ekonomi tersebut tentu bukan ranahnya Kemenkopolhukkam, Kemhan, Polri, maupun TNI. Namun merupakan ranah dari Kemenko Perekonomian, Kementerian Pertanian, Kemenaker, Kemendag, dan lain sebagainya.

Output yang diharapkan dalam penanganan AKN adalah adanya kecepatan dan keterpaduan aksi sejumlah instansi negara dalam penanganan AKN. Keempat negara di atas memiliki lembaga koordinasi di tingkat strategis yang dinamakan National Security Council. Hal itu menegaskan kembali betapa peran Wankamnas merupakan suatu keniscayaan.

Namun sebaiknya Pemerintah Indonesia tidak terbelenggu dalam ketiadaan Wankamnas dan berupaya mengoptimalkan struktur birokrasi yang ada untuk menjalankan fungsi Wankamnas (atau untuk mempersiapkan diri dalam membentuk Wankamnas di kemudian hari). Kecepatan dan keterpaduan aksi antar instansi dapat dibangun melalui mekanisme yang selama ini telah berjalan, yaitu melalui Rapat Kabinet Terbatas (RKT) bidang Hankam. Presiden dapat secara berkala mengundang pejabat terkait seperti: Wapres, Menkopolhukkam, Menhan, Menlu, Mendagri, Panglima TNI, Kapolri, Kepala BNPT dan Wantimpres. Pada Pemerintahan Presiden Jokowi, telah ditetapkan jabatan baru yaitu Kepala Staf Kepresidenan (KSK) yang mengepalai Unit Staf Kepresidenan (USK). KSK ini hampir sama dengan jabatan Kepala Staf Gedung Putih di AS. KSK juga kerap diundang dalam rapat kabinet terbatas.

Menurut Wiranto, pembahasan lintas sektoral telah dilaksanakan Pemerintah Indonesia. Di mulai Rapat Koordinasi Tingkat Ekselon II terkait dan diteruskan Rapat Koordinasi Tingkat Ekselon I. Bilamana diperlukan keputusan Menko terkait, maka diadakan Rapat Paripurna Tingkat Menteri (RPTM). Hasil RTPM yang urjen atau yang memerlukan keputusan presiden akan dibawa ke Istana dalam Rapat Terbatas (Ratas) yang dipimpin oleh presiden dan dihadiri para Menko dan menteri terkait. Di era Presiden Jokowi, Ratas dapat dilaksana lebih dari dua kali dalam sehari. Hal itu menunjukkan intensi Presiden Jokowi untuk mengatasi masalah strategis dengan cepat. Sistem koordinasi yang bangun bersifat bottom-up (Wiranto dan Surya 2017).

Untuk fungsi analisis dan kajian Keamanan Nasional (Lemhannas RI 2018) perlu dipertimbangkan untuk diemban oleh Lembaga Ketahanan Nasional RI. Dengan didukung oleh sejumlah akademisi dan pejabat senior dari lingkungan TNI dan Polri, Lemhannas sudah memiliki modalitas untuk menjadi think-tank utama untuk mengkaji Keamanan Nasional. Lemhannas memiliki kurikulum Program Pendidikan Reguler Angkatan (PPRA) tentang simulasi atas perubahan lingkungan strategis yang dinamakan Olah Sistem Manajemen Nasional (Sismennas). Olah Sismennas ini dapat dikembangkan sebagai situation awareness center (SAC) khusus untuk Keamanan Nasional yang dikaji oleh pakar-pakar akademisi dari sejumlah perguruan tinggi maupun lembaga kajian. Oah Sismennas Lemhannas ini diharapkan dapat melengkapi SAC yang dibangun Kemenkopolhukkam RI. 
Gambar 1. Peran Lemhannas RI adalah dalam memberi input ke aktor Pemerintah

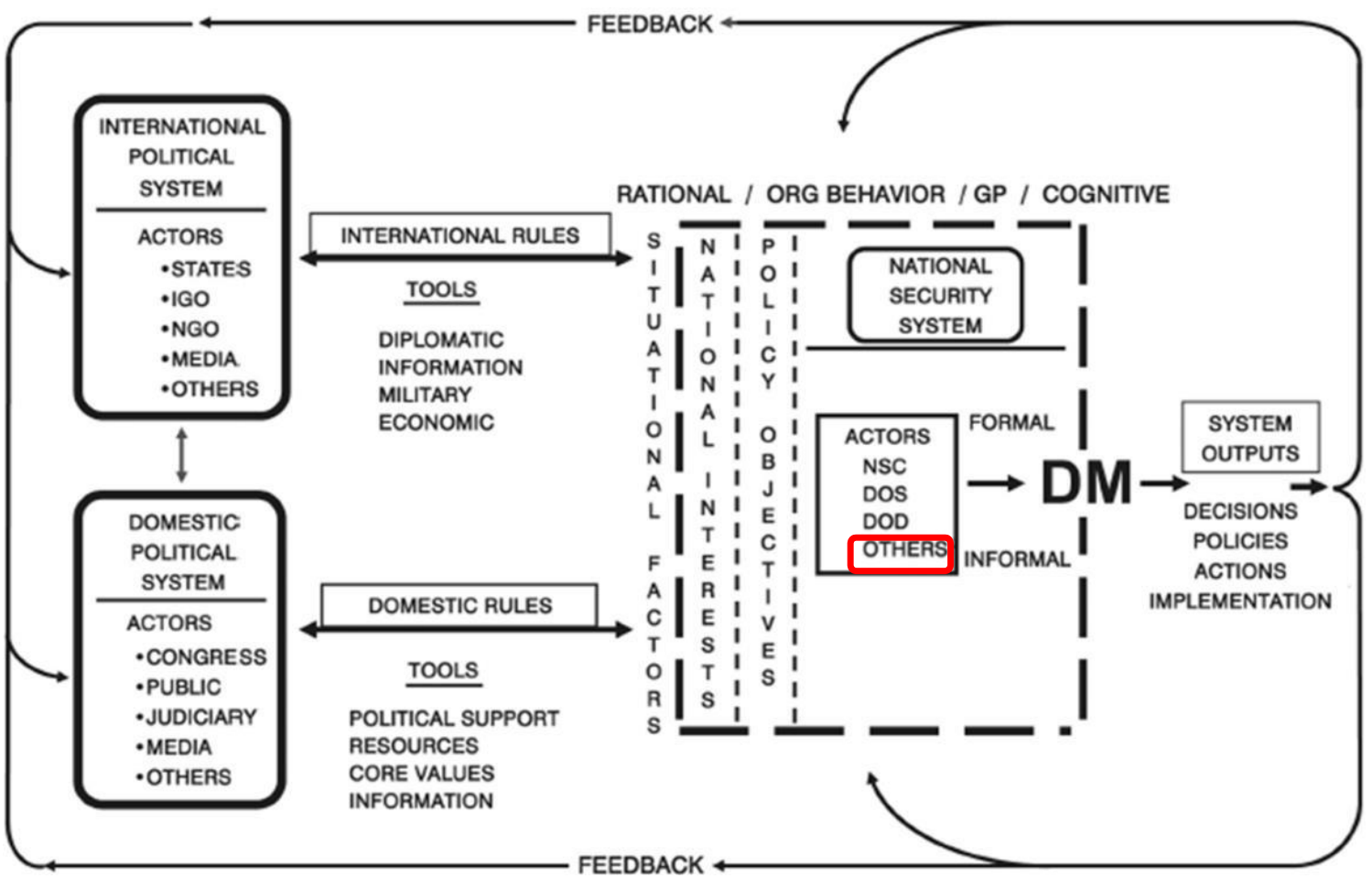

Sumber: Yanyan M. Yani dan Ian Montratama (2016)

Dengan maksud mempertegas pembagian tugas dan peran dari sejumlah instansi yang terkait penanganan Keamanan Nasional di Indonesia, berikut ini usulan penulis yang digambarkan dalam bentuk chart di halaman berikutnya. Fungsi Wantannas di tingkat strategis (baca: kabinet) dapat dilakukan dalam forum Rapat Kabinet Terbatas bidang Hankam yang diketuai oleh Presiden. Anggota forum ini umumnya dihadiri oleh Wapres, Menkopolhukkam, Menhan, Mendagri, Menkominfo, Panglima TNI, Kapolri, Mensekneg, Mensekkab, Kepala Staf Kepresidenan, Kepala BIN, Jaksa Agung, Kepala Lemhannas, Kepala Wantannas, dan Wantimpres bidang Hankam (serta pejabat lain yang dianggap perlu). Tujuan dari forum ini adalah menyelaraskan kebijakan strategis lintas instansi pemerintah demi terciptanya keterpaduan kebijakan strategis yang lebih antisipatif dan responsif dalam menangani masalah AKN. Birokrasi dan regulasi yang dianggap menghambat dapat dibenahi sesuai dengan kewenangan anggota Kabinet.

Lemhannas RI berperan dalam membantu memberikan kajian strategis yang signifikan dalam menghasilkan kebijakan Pemerintah yang berkualitas. Jika di Amerika Serikat, lembaga kajian seperti ini sangatlah terpandang, seperti RAND Corporation, Carnegie Institute, CSIS, the Heritage, IDSS-NTU \& ISEAS. Output Lemhannas RI adalah berupa rekomendasi dan analisa kebijakan, termasuk kajian strategis keamanan nasional untuk Kantor Kepresidenan, Kemenkopolhukkam, Kemhan, Kemlu, Kemdagri, dan Mabes TNI (lihat gambar tentang peran lembaga kajian strategi dalam proses pengambilan kebijakan di Pemerintah). Produk lain dari Lemhannas RI merupakan kajian perspektif ancaman nasional.

Kebijakan yang ditetapkan di level kabinet perlu dikawal agar dapat dilaksanakan di 
tingkat operasional di setiap lembaga pemerintah setingkat kementerian. Untuk itu perlu adanya forum koordinasi di bawah Menkopolhukkam yang membawahi Deputi Hankam Kemenkopolhukkam, Menhan, Mendagri, Menkominfo, Panglima TNI, Kapolri, Mensekneg, Mensekkab, Kepala Staf Kepresidenan, Kepala BIN, Jaksa Agung, Kepala Lemhannas, Sekjen Wantannas, dan Wantimpres bidang Hankam (serta pejabat lain yang dianggap perlu). Tujuan dari forum komunikasi ini adalah mengoptimalkan implementasi dari kebijakan strategis yang telah ditetapkan oleh Presiden. Menkopolhukkam diberi kewenangan untuk menetapkan sasaran dan memonitor kinerja dari sejumlah intansi terkait.

Sementara untuk level taktis, perlu adanya penguatan peran lembaga Dewan Ketahanan Nasional (Wantannas) RI dengan dilembagakannya forum koordinasi penanganan AKN di level sekretariat jenderal di kementerian. Hal ini dimaksudkan untuk menjamin koordinasi yang lebih harmonis antar lembaga terkait dalam menangani AKN. Sekjen Wantannas RI diberi wewenang untuk memimpin forum kordinasi yang terdiri dari Deputi Hankam Kemenkopolhukkam, Sekjen Kemhan, Sekjen Kemdagri, Sekjen Kemkominfo, Kasum Panglima TNI, Wakapolri, Mensekneg, Sekmen Setneg, Deputi Hankam Setkab, Deputi Manajemen Isu Strategis USP, Settama BIN, Wakil Jaksa Agung, Settama Lemhannas, Settama BNPT, dan Wantimpres bidang Hankam (serta pejabat lain yang dianggap perlu). Tujuan forum ini bukan untuk deregulasi maupun debirokrasi, melainkan untuk menjamin sistem penanganan terorisme yang dibangun dapat dijalankan seoptimal mungkin (dengan memitigasi ego sektoral yang mungkin terjadi).

Untuk meningkatkan fungsi deteksi, pencegahan, dan perlindungan AKN; peran badan intelijen sangat dominan. BIN sebagai badan intelijen yang berkedudukan tertinggi perlu diberi wewenang untuk memimpin forum koordinasi lembaga intelijen di Indonesia yang beranggotakan Kepala BAIS, Sekjen Kemkominfo, Kepala Baintelkam Polri, dan Kepala Badan Informasi Geospasial (serta pejabat lain yang dianggap perlu). Keseluruh badan intelijen terkait harus memiliki sistem informasi yang terpadu serta struktur intelijen yang sistematis agar terhindar dari duplikasi dan konflik di lapangan. Ego sektoral yang kerap terjadi di lingkungan intelijen harus dapat dibenahi melalui koordinasi BIN.

Dalam fungsi penindakan AKN, TNI dan POLRI yang merupakan leading sector tergantung dari jenis AKN-nya. Pemimpin kedua instansi secara bergantian perlu diberi kewenangan untuk memimpin forum koordinasi dengan sejumlah instansi terkait yang memiliki kemampuan penanggulan AKN terkait yang diwakili oleh Kasum TNI, Wakapolri, Pangkostrad, Danjen Kopassus, Dankormar, Dankorpaskhas, dan Dankorbrimob, dan Wakil Jaksa Agung (serta pejabat lain yang dianggap perlu). Panglima TNI dan/atau Kapolri harus mampu untuk menjamin penindakan AKN dapat dilaksanakan dengan selaras antar instansi terkait, tanpa menimbulkan kesan ego sektoral. Bahkan sebaiknya, Panglima TNI/Kapolri harus mampu mengoptimalkan peran satuan masing-masing sedemikian rupa agar respons atas AKN di mana saja dapat selalu ditingkatkan.

Peran kajian harus diperhatikan pemerintah dengan seksama. Setiap AKN harus dapat dikaji, diprediksi dan diantisipasi penanganannya. Perlu adanya instansi pemerintah yang ditugasi untuk melakukan kajian AKN secara profesional. Sudah sepantasnya Gubernur Lemhannas RI diberi wewenang untuk memimpin forum koordinasi yang terdiri dari Kepala BIN, Kepala BAIS, Sekjen Kemkominfo, Kepala Baintelkam Polri, Settama BNPT, Sekjen Kemdagri, dan Wamenlu (serta pejabat lain yang dianggap perlu) untuk menetapkan sistem kajian yang efektif dan efisien dalam memonitor dan mengantisipasi AKN aktual maupun potensial. Forum kajian ini harus mampu potensi hambatan birokrasi dalam penanganan AKN. Produktivitas kajian yang tepat guna dan tepat waktu akan memiliki efek multiplyer 
yang besar dalam penanganan AKN, jika dibandingkan dengan upaya penindakan.

Gambar 2. Forum Koordinasi Penanganan Keamanan Nasional di Tingkat Strategis

Yang diketuai: Presiden RI

Yang beranggotakan: Wapres, Menkopolhukkam, Menhan, Mendagri, Menkominfo, Panglima TNI, Kapolri, Mensekneg, Mensekkab, Kepala Staf Kepresidenan, Kepala BNPT, Kepala BIN, Jaksa Agung, Gubernur Lemhannas, Sekjen Wantannas, dan Wantimpres bidang Hankam (serta pejabat lain yang dianggap perlu)

\begin{tabular}{l} 
Forum koordinasi penanganan AKN \\
di tingkat operasional: \\
\multicolumn{1}{|c|}{ Kemenkopolhukkam } \\
\hline $\begin{array}{l}\text { Yang diketuai: Menkopohukkam } \\
\text { Yang beranggotakan: Deputi Hankam } \\
\text { Kemenkopolhukkam, Menhan, Mendagri, } \\
\text { Menkominfo, Panglima TNI, Kapolri, } \\
\text { Mensekneg, Mensekkab, Kepala Staf } \\
\text { Kepresidenan, Kepala BNPT, Kepala BIN, } \\
\text { Jaksa Agung, Gubernur Lemhannas, Sekjen } \\
\text { Wantannas, dan Wantimpres bidang } \\
\text { Hankam (serta pejabat lain yang dianggap } \\
\text { perlu) }\end{array}$ \\
\hline
\end{tabular}

\section{Forum koordinasi penanganan AKN} di tingkat taktis:

\section{Dewan Ketahanan Nasional}

Yang diketuai: Sekjen Wantannas

Yang beranggotakan: Deputi Hankam

Kemenkopolhukkam, Sekjen Kemhan,

Sekjen Kemdagri, Sekjen Kemkominfo,

Kasum Panglima TNI, Wakapolri,

Mensekneg, Sekmen Setneg, Deputi

Hankam Setkab, Deputi Manajemen Isu

Strategis USP, Settama BIN, Wakil Jaksa

Agung, Settama Lemhannas, Ka BNPT,

dan Wantimpres bidang Hankam (serta

pejabat lain yang dianggap perlu)

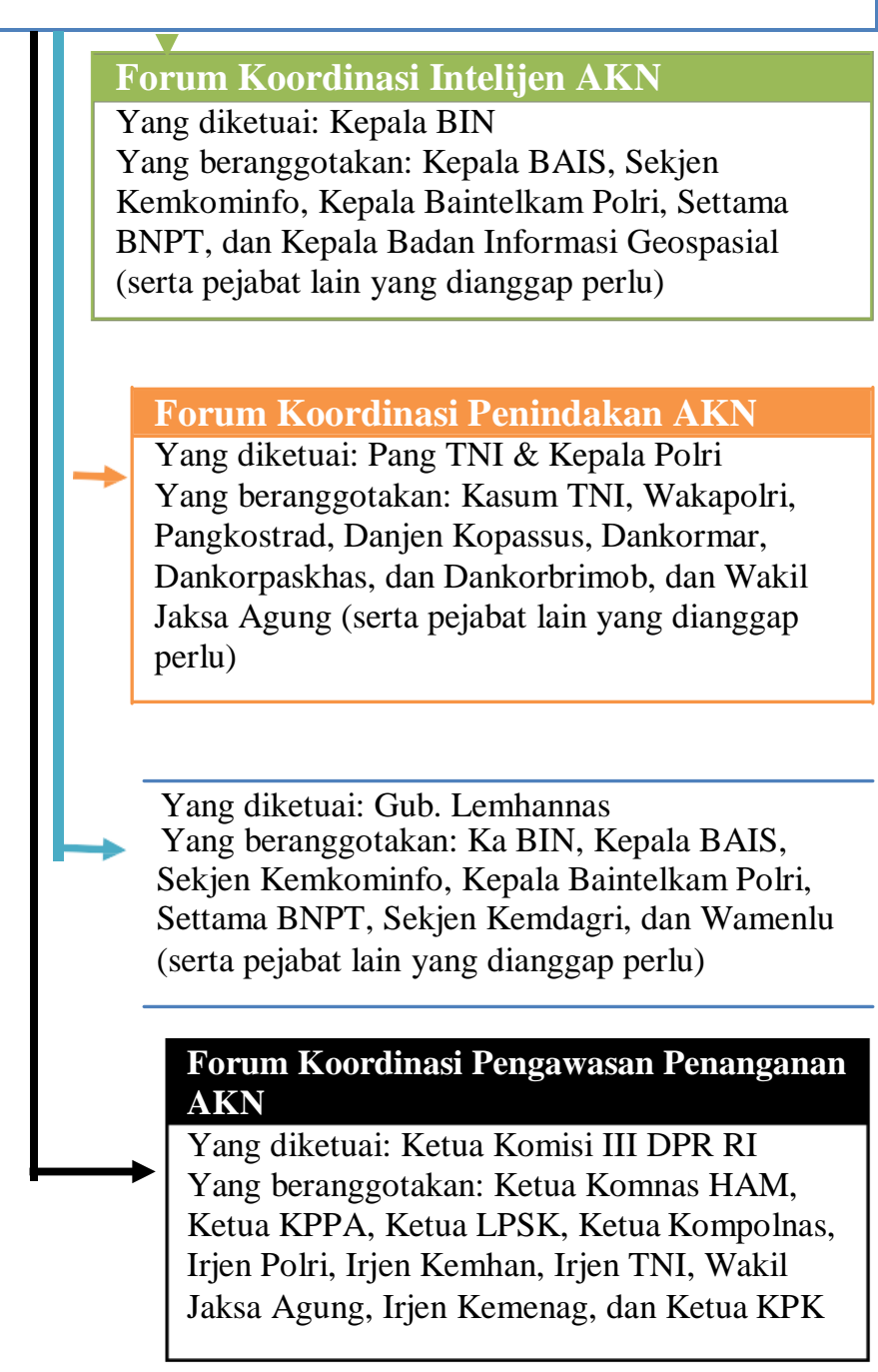

Sumber: Yanyan M. Yani dan Ian Montratama (2016)

Gubernur Lemhannas RI dapat berperan seperti National Security Advisor di Amerika Serikat. National Security Advisor dalam sistem birokrasi Indonesia belum dikenal. Namun Gubernur Lemhannas RI memiliki tugas dan tanggung jawab yang menyerupai NSA di AS. Tugas Gubernur Lemhannas RI adalah menyelenggarakan pengkajian yang bersifat konsepsional dan strategis mengenai berbagai permasalahan nasional, regional dan 
internasional yang diperlukan oleh Presiden, guna menjamin keutuhan dan tetap tegaknya Negara Kesatuan Republik Indonesia (Lemhannas 2018). Pemberian kajian tersebut wajib dilakukan oleh Gubernur baik diminta ataupun tidak oleh Presiden. Atas permintaan Presiden, Gubernur dapat mengikuti sidang kabinet serta kunjungan kerja dan kunjungan kenegaraan. Dalam melaksanakan tugasnya, Gubernur dapat meminta informasi dari instansi pemerintah terkait dan lembaga negara lainnya.

Peran NSA dalam birokrasi AS yang sangat strategis dapat dijadikan referensi bagi Gubernur Lemhannas RI untuk menawarkan nilai strategis dalam proses pengambilan keputusan Presiden RI bidang hankam/Keamanan Nasional. Gubernur Lemhannas RI dapat menyiapkan informasi yang bermutu berdasarkan kajian akademis yang sesuai dengan kaidah metode ilmiah. Gubernur dapat berkonsentrasi penuh dalam kajian Keamanan Nasional tanpa disibukkan dengan urusan birokrasi protokoler yang menyita waktu dan bebas dari tekanan politik. Gubernur dapat menjadi sumber informasi terpercaya yang menggabungkan informasi dari berbagai instansi Pemerintah dan swasta.

Struktur penanganan AKN harus pula memasukkan peran pengawasan. Hal ini dikarenakan sebagai negara demokrasi, seluruh tindakan aparatur pemerintah kepada masyarakatnya harus selalu menjunjung tinggi hak asazi manusia. Karena penanganan AKN dilakukan oleh pemerintah, maka pihak yang paling tepat dalam mengawasinya adalah dari unsur legislatif, lebih khusus lagi diketuai oleh Ketua Komisi III DPR RI yang membidangi masalah Hukum, HAM, dan Keamanan. Forum koordinasi pengawasan penanganan AKN ini sebaiknya beranggotakan pemimpin lembaga-lembaga terkait pengawasan seperti Ketua Komnas HAM, Ketua KPPA, Ketua LPSK, Ketua Kompolnas, Irjen Polri, Irjen Kemhan, Irjen TNI, Wakil Jaksa Agung, Irjen Kemenag, dan Ketua KPK.

Akhirnya, artikel ini hanya membahas tentang struktur organisasi penanganan AKN secara lintas lembaga pemerintah. Namun efektivitas dari penanganan AKN bergantung pada proses organisasinya. Perlu adanya kajian terpisah tentang proses organisasi yang meliputi tentang konsep nilai (seperti mengutamakan kepentingan nasional daripada kepentingan kelompok dan seluruh satuan organisasi memiliki kesamaan tujuan besar) dan budaya organisasi (seperti konsistensi, akuntabel, transparan, saling membantu walau berbeda satuan, bekerja keras, dan lain sebagainya). Membangun proses organisasi yang efektif dan efisien memilki tantangan yang lebih besar karena meliputi perubahan sosial dalam membentuk karakter dan mental aparatur negara sesuai dengan struktur yang telah ditetapka 


\section{DAFTAR PUSTAKA}

\section{Buku}

Anwar, Dewi Fortuna. 2004. Demokrasi, Keamanan dan Peranan Militer. Jakarta: LIPI. Bandoro, Bantarto. 2005. Perspektif baru Keamanan Nasional. Jakarta: CSIS.

Burke, John P. 2009. The National Security Advisor and Staffs. Washington D.C.: The Whitehouse Transition Projects.

Carpenter, Williams dan David Wiencek. 2005. Asian Security Handbook: Terrorism and The New Security Environment. New York: M E Sharpe Inc.

Singapore, The Government of. 2004. The Fight Against Terrorist: Singapore's National Security Strategy. Singapura: Ministry of Defence.

Tan, Andrew Tan dan Kumar Ramakrishna. 2002. The New Terrorism: Diagnosis and Prescriptions. Singapura: Eastern Universities Press.

Yunanto, Sri. 2005. The Rise of Radical Islamist Groups in Indonesia and the Political and Security Consequences of Their Political Activities dalam Democratization and the Issue of Terrorism in Indonesia. Jakarta: Konrad-Adenauer-Stiftung e.v.

\section{Jurnal}

Vermonte, J Philips. 2003. "Isu Terorisme dan Human Security, Implikasi terhadap Studi Kebijakan Keamanan Global.” Jurnal Ilmu Politik FISIP UI.

Yani, Yanyan M. dan Ian Montratama. 2016. "Mengenal Dewan Keamanan Nasional di Empat Negara sebagai Referensi Pembentukan Struktur Koordinasi Penanganan Terorisme di Indonesia." Jurnal Unhan, Edisi April 2016.

\section{Website}

ANAO. 2011. Audit Report No.29 2010-11. Management of the Implementation of New Policy Initiatives. Diakses pada tanggal 4 Maret 2016. http://www.anao.gov.au/html/Files/BPG\%20HTML/Audit\%20Report\%20No\%2029\%2 02010\%2011/6/5/index.html

Clark, Muradi. 2009. Densus 88 AT: Peran dan Koordinasi Dalam Pemberantasan Terorisme di Indonesia. Diakses pada tanggal 4 Maret 2016.

https://muradi.wordpress.com/2009/05/12/densus-88-at-peran-dan-koordinasi-dalampemberantasan-terorisme-di-indonesia/

Departemen Perdana Menteri dan Kabinet Australia. 2016. Diakses pada tanggal 4 Maret 2016. https://www.dpmc.gov.au/pmc/about-pmc/core-priorities/national-security-andinternational-policy

Gedung Putih. 2016. Statement by the President on the White House Organization for Homeland Security and Counterterrorism. Diakses pada tanggal 4 Maret 2016. https://www.whitehouse.gov/the-press-office/statement-president-white-houseorganization-homeland-security-and-counterterrorism

Institute Defence and Security Peace Studies (IDSPS). 2010. Diakses pada tanggal 30 November 2010. www.idsps.org 
Kejaksaan Agung Australia. 2016. Diakses pada tanggal 4 Maret 2016.

https://www.protectivesecurity.gov.au/governance/Pages/Australian-Governmentprotective-security-roles-and-responsibilities.aspx

Kementerian Kehakiman AS. 2016. Diakses pada tanggal 4 Maret 2016. https://www.justice.gov/archive/ll/highlights.htm

Kementerian Pertahanan Singapura. 2016. Fact Sheet: Security Policy Review Committee. Diakses pada tanggal 4 Maret 2016.

http://www.mindef.gov.sg/imindef/press_room/official_releases/nr/2009/feb/23feb09_n r/23feb09_fs3.html\#.VtkJZeYT3Bs

Lemhannas RI. 2018. Situs resmi Lemhannas RI. Diakses pada tanggal 30 April 2018. http://www.lemhannas.go.id/index.php/tentang-lemhannas/kedudukan-tugas-danfungsi.html

National Security Coordination Centre. 2004. "Fight Against Terror: Singapore's National Security Strategy." National Security Coordination Centre. Diakses pada tanggal 4 Maret 2016. mercury.ethz.ch/serviceengine/Files/ISN/.../Singapore-2004.pdf

National Security Coordination Secretariat. 2016. Diakses pada tanggal 4 Maret 2016. http://www.nscs.gov.sg/public/content.aspx?sid=23

NEFA Foundation. 2016. Summary of Case Against Jemaah Islamiyah (Singapore) dalam Annex A. Diakses pada tanggal 5 Mei 2015. http://nefafoundation.org/miscellaneous/FeaturedDocs/SingMHA_JISummary.pdf

NST. 2015. National Security Council Bill Approved. Hakam. Diterbitkan pada tanggal 3 Desember 2015. Diakses pada tanggal 2 Maret 2015. http://hakam.org.my/wp/index.php/2015/12/03/national-security-council-bill-approved/

Pemerintah Amerika Serikat. 1947. National Security Act 1947. Diakses pada tanggal 4 Maret 2016. https://assets.documentcloud.org/documents/2695389/1947-National-SecurityAct.pdf

Pemerintah Australia. 1995. Criminal Code Act 1995. Diakses pada tanggal 4 Maret 2016. https://www.nationalsecurity.gov.au/WhatAustraliaisdoing/Documents/ProtocoForDecl aringAnArea.pdf

Pemerintah Australia. 2010. Buku Putih Penanganan Terorisme Australia. Counter-Terrorism White Paper. Diakses pada tanggal 4 Maret 2016.

https://www.asio.gov.au/img/files/counter-terrorism_white_paper.pdf

RSIS. 2016. CENS. Diakses pada tanggal 4 Maret 2016. http://www.rsis.edu.sg/research/cens/

Thiru, Steven. 2015. "The National Security Council Bill 2015 is a Lurch Towards an Authoritarian Government." The Malaysian Bar, diterbitkan pada tanggal 3 Desember 2015. Diakses pada tanggal 4 Maret 2016.

http://www.malaysianbar.org.my/press_statements/press_release_|tthe_national_securit y_council_bill_2015_is_a_lurch_towards_an_authoritarian_government.html

Undang Undang NSC Malaysia. 2015. Diakses pada tanggal 2 Maret 2015. https://www.cljlaw.com/files/bills/pdf/2015/MY_FS_BIL_2015_38.pdf

Wahid, Chairul. 2011. "Keamanan Nasional dan UU Intelijen.” Kompas. Diakses pada tanggal 16 April 2016. http://www.kompasiana.com/walid/keamanan-nasional-dan-uuintelijen_55006d8b813311491afa77c3

Wulandari, Indah dan Endro Yuwanto. 2010. "Densus 88 Arogan di Medan, IPW Desak DPR Panggil Kapolri.” Diterbitkan oleh Republika.co.id pada tanggal 22 September 2010. Diakses pada tanggal 4 Maret 2016 dari: http://www.republika.co.id/berita/breaking- 
news/hukum/10/09/22/135890-densus-88-arogan-di-medan-ipw-desak-dpr-panggilkapolri 